\title{
Social Security Incentives For Retirement In Italy
}

Luca Spataro, (E-mail: 1.spataro@ec.unipi.it), Università di Pisa, Italy

\begin{abstract}
The present work is the first of a two-paper project aiming at bringing a new empirical contribution to literature on retirement, with particular focus on Italy. In this paper I carry out an analysis of Social Security-provided incentives for early retirement and of the main changes brought about by the two major early 90s reforms. For this purpose I use a sample of male employees drawn from the Bank of Italy Survey on Wealth and Income of Italian Households (SHIW) and I calculate both "static" and "dynamic" SS incentive measures: as for the latter, I discriminate between "one year" and "lifetime" measures of the accumulation opportunities of SS entitlements and suggest new measures to account for the trade-off comprised in the decision of retirement. The analysis documents strong early retirement incentives for Public Sector employees and relevant binding eligibility constraints for Private Sector workers. In general prosecution of work beyond age 60 has been dramatically discouraged due to the actuarial unfairness of pension formula. As for the effects of the SS reforms, it emerges that the early 1990s changes will produce a strong cut of benefits in the long run, while for current employees the most important changes have been the reduction of benefit indexation, the temporary restrictions and actuarial penalizations on seniority retirement. It turns out that especially Public Sector employees and younger cohorts undergo the strongest benefit cuts. All in all, to the extent to which such benefit cuts have been perceived by individuals, one would expect reforms to have induced anticipated exits from labor force among older cohorts.
\end{abstract}

\section{Introduction}

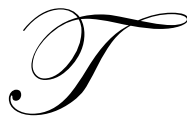

he relationship between Social Security (SS from now on) provision and retirement choices has been especially studied over the last decades. As documented in Coile and Gruber (2000a), previous literature dating from 1970s has concluded that SS changes have a significant, but modest effect on retirement dates in the U.S.. On the other hand and more plausibly, more recent studies have questioned such results, by bringing evidence of a stronger, crucial role played by SS incentives in explaining workers' retirement behavior. The latter approaches, in particular, have pointed out that retirement is, typically, a decision taken by forward looking individuals, who, while maximizing a life-time "revenue" function in an uncertain environment, contrast the present SS wealth accumulation opportunities with those at some time in the future. In fact, starting from the work by Stock and Wise (1990) on the Option Value of retirement, a number of works have shared this assumption and assessed its relevance by both estimating structural forms (like Gustman and Steinmeier (1986) and Rust and Phelan (1997)) and reduced forms of retirement decisions by allowing for forward-looking behavior through the specification of certain SS measures (see Lumsdaine, Stock and Wise (1992), Samwick (1998), Coile and Gruber (2000b) and Chan and Stevens (2001)). As for Italy, studies assessing the determinants of retirement are very recent and results are somehow still contradictory ${ }^{1}$ (see next paragraph for a brief review). Besides being a deficiency per se, such lack of univocal answers impedes any serious forecast about the effectiveness of past and future reforms in improving activity rates. In fact, Italy underwent major reforms in the last decade which have strongly reduced SS benefits and changed the life-time pattern of the mentioned incentives. Yet, only few works have investigated the implications of these changes on retirement behavior.

The present work is the first of a two-paper project aiming at providing a new contribution to this strand of literature. For this purpose I propose some new measures of Social Security incentives for anticipated retirement: the 
first of them is called the Marginal Cost of Retirement (MCR), which captures the trade-off comprised in the choice of delaying retirement by one year. The second is a lifetime extension of the MCR and is referred to as the Minimum Cost Value (MCV). Finally, following the same strategy, I present an extension of the already existing Accruals, which I call the Minimum Tax Value (MTV). I also compare these new measures with those adopted in previous studies. The paper proceeds as follows: I begin with the institutional features of the Italian SS system prior to and after 1990s reforms respectively. Next, after sketching the main findings of previous related literature in Italy, I describe the new measures I use for capturing the retirement incentives. In the following sections I describe the data used in the analysis and present the main results. Final remarks conclude.

\section{Background}

\subsection{Institutional features of Social Security in Italy prior to and after the 90s reforms}

Before 1990s reforms the Italian SS scheme was a mandatory, Pay-As-You-Go system providing two types of defined benefit pensions: the "old age pensions" and "seniority pensions"; the former could be claimed conditional on the achievement both of age 60 and at least 15 years of SS tax payment. To the latter were entitled individuals who, no matter how old, had completed at least 35 years of contribution payment, or 20 years if working in the Public Sector. Eligibility rules were even more favorable to women and relatively different (but generous as well) for self-employed. The National Fund also provided a means-tested income maintenance scheme for individuals over 65 not covered by old-age insurance (minimum benefit scheme), and, among other non contributory provisions, survivor benefits and disability pensions. The system was (and still is) financed by both employers and employees contributions, with an overall payroll tax of about $26 \%$ of gross earnings up to 1992. Employees also contributed a further $7.41 \%$ to a "severance pay fund" called $T F R$, managed by the firm and yielding a legislated rate of return (1.5\% plus $3 / 4$ of yearly inflation rate). Retirement at the "normal age" (age 60 ) was not mandatory, in that a worker could postpone retirement up to age 65 in order to complete (no more than) 40 years of contributions. As for benefit computation, the formula was given by the product of three elements: the "interest yield", the number of contribution years paid to the Fund and the "pensionable wage" (see Table 4 for the explanation of such parameters): for Private Sector employees no more than $80 \%$ of pensionable wages were attainable at the moment of retirement, while, due to more generous rules, State employees could a more than $90 \%$ replacement ratio upon retirement. Finally, pensions were indexed according to the nominal wages growth rate. As a consequence, the system typically provided more than actuarially fair pensions, since the latter were independent of the amount of contributions paid while working. Moreover the almost continuous changes operated by the Parliaments towards increasing generosity have led to the crisis of early 90's and to the corrections introduced by the 1993, 1995 and subsequent reforms.

In short, these reforms have tightened eligibility requirements, reduced the SS wealth (especially thanks to the indexation of benefits according to a price index), increased the payroll taxes up to about $33 \%$ for employees, moved the system towards a "contribution-defined" mechanism and initiated an harmonization process of the rules among the several National Funds (for example, caps for pensionable earnings and differentiation of the internal yield according to wage brackets were introduced also for Public Sector employees, SS payroll taxes for selfemployed were progressively increased in order to reduce the gap with other categories): these measures, as it has been claimed by some authors ${ }^{2}$, should be able to stabilize, although only in the long-run, the ratio of pensions expenditure to GDP. In fact, the way the reforms have been phased in, so that the actuarially fair computation mechanism and some minor changes do not even apply to some category of workers (according to seniority criteria), slackens the positive effects on the State unbalances so much that Italy will face SS deficits in the next decades and experience a hump of SS expenditure-to-GDP ratio by the early 30's of the current century ${ }^{3}$. For these reasons calls for new corrections SS rules of such distortions are made systematically.

\section{The SS incentive measures}

I now turn to the presentation of the SS incentive measures used in the analysis, starting from the one referred to as the Marginal Cost of Retirement (MCR). Let us image an individual is assessing the possibility of leaving her job and, thus, retiring in the current year, the latter being also the first period in which eligibility is 
achieved. I assume that decisions (and wage or pension benefits) occur at the beginning of each year; the agent can decide whether working or not for one year more, but the amount of time on the job is given and normalized to 1. Thus, by leaving in current year $t$, the agent gives up her current wage (net of pension payroll tax) and obtains a flow of pension benefits up to year $D$, which is usually referred to as "SS wealth" 4 . Formally:

$$
F_{L, t}=(1-\tau) \cdot W_{L+1, t}-\sum_{i=1}^{D-t} \frac{P_{L, t+i-1}}{(1+r)^{i-1}},
$$

where $W_{L+1, t}$ is the wage of year $t$ after $L+1$ years of work, $\tau$ is the contribution tax rate, $P_{L, t+i-1}$ is the annual pension amount corresponding to the minimum number of contributions $(L)$ needed for eligibility, $r$ is the interest rate, supposed constant for simplicity. On the other hand, In case she keeps on working another year, she "gains" the flow of benefits:

$$
F_{L+1, t}=-\sum_{i=1}^{D-(t+1)} \frac{P_{L+1, t+i}^{\prime}}{(1+r)^{i}}
$$

By subtracting expression [2] from [1] we get the Marginal Cost of Retiring in year $t$, which is:

$$
M C R_{L / L+1, t}=(1-\tau) \cdot W_{L+1, t}+\sum_{i=1}^{D-(t+1)} \frac{P_{L+1, t+i}^{\prime}}{(1+r)^{i}}-\sum_{i=1}^{D-t} \frac{P_{L, t+i-1}}{(1+r)^{i-1}} .
$$

More generally, in each future year $t+j$, one has:

$$
M C R_{L+j / L+1+j, t+j}=(1-\tau) \cdot W_{L+j+1, t+j}+\sum_{i=1}^{D-(t+j+1)} \frac{P_{L+j+1, t+j+i}^{\prime}}{(1+r)^{i}}-\sum_{i=1}^{D-(t+j)} \frac{P_{L+j, t+j+i-1}}{(1+r)^{i-1}}
$$

with $j=0,1 \ldots(\bar{L}-L)$, where $\bar{L}$ is the maximum number of working years fixed by the law. Finally, by dividing expression [3'] by the current wage, we get the Rescaled MCR. Intuitively, should the benefit formula be actuarially fair (or pensions not provided at all), the cost of retiring would be the current wage, thus reproducing a well known result stemming from microeconomic theory on labor supply. In all other cases, being the cost either bigger or lower than the wage, a distortion of work/leisure choice and, consequently, welfare losses would be brought about ${ }^{5}$. Notice that the $R M C R$ is quite close to the to the implicit tax/subsidy of postponing retirement used, among others, by Brugiavini (1999) and by Coile and Gruber (2000a), which I indicate as $B_{L+j / L+1+j, t+j}$; it is defined as the ratio between the expected present value of future pension benefits accrual (with negative sign), obtained from postponing retirement by one year, and the current period wage. Formally:

$$
B_{L+j / L+1+j, t+j}=-\frac{1}{W_{L+j+1, t+j}}\left[\sum_{i=1}^{D-(t+j+1)} \beta^{i} P_{L+j+1, t+j+i}^{\prime}-\sum_{i=1}^{D-(t+j)} \beta^{i-1} P_{L+j, t+j+i-1}\right] \equiv-\frac{A C C R_{t}}{W_{L+j+1, t+j}}
$$

where $\beta$ is the intertemporal discount factor; now, supposing $\beta$ and $r$ equal to 1 and 0 respectively, for the sake of simplicity, the following relationship holds: $R M C R_{L+j / L+1+j, t+j}=\left\lfloor-B_{L+j / L+1+j, t+j}+(1-\tau)\right\rfloor$ Consequently, if the system is actuarially fair, so that $M C R_{L+j / L+1+j, t+j}=W_{L+j+1, t+j},($ or $R M C R=1)$ then $B_{L+j / L+1+j, t+j}=-\tau$. On the contrary, there is an incentive to early retirement if and only if

$$
M C R_{L+j / L+1+j, t+j}<W_{L+j+1, t+j} \Leftrightarrow R M C R_{L+j / L+1+j, t+j}<1 \Leftrightarrow B_{L+j / L+1+j, t+j}>-\tau .
$$


From the relationships above it can be said that the third inequality to hold, rather than the positive sign of $B$ (that is a positive accrual) is a necessary and sufficient condition for the presence of early retirement incentives ${ }^{6}$. In this sense, the $(R) M C R$ seems more coherent with the microeconomic theory on labor supply and gives an immediate and exact measure of the incentive to early retirement.

A straightforward extension of such parameter is what I call the Minimum Cost Value (MCV) of retirement, that is the difference between the minimum marginal cost of postponing retirement in the future and the current date marginal cost. Formally:

$$
M C V_{t}=\min \left(M C R_{t+j}-M C R_{t}\right) \text { with } j=1 \ldots(\bar{L}-L) .
$$

In other words, this parameter allows for possibility that individuals: i) face a longer time-horizon than a single year time-span; ii) compare not just the difference between flows of benefits (like in the Peak Value case) or values (like in the Option Value) but the "marginal costs": in particular, in case the marginal cost reduces as at some older age, so that $M C V_{t}<0$, it is more convenient for individuals to postpone retirement. Again, were the SS system actuarially fair, (so that the $M C R$ in each period would equal the current salary) the decision to retire would be completely led by the difference between future and present wages. Henceforth, in order to disentangle the effect of wage changes from the SS variation, I will also use a rescaled measure of the $M C V$, that is the difference between the minimum expected future $R M C R$ and the current one:

$$
R M C V_{t}=\min \left(R M C R_{t+j}\right)-R M C R_{t} \quad \text { with } j=1 \ldots(\bar{L}-L) .
$$

Analogously, one can extend the same reasoning to the Accruals, and build-up the following measure, which I call the Minimum Tax Value (MTV); I define such measure as the difference between the Maximum expected value of the Accruals (with reversed sign, which can be interpreted as the minimum tax levied upon the decision of anticipating retirement by one year) and the value (with reversed sign as well) associated to the current year. By calling the negative of the Accrual as the Absolute Tax (ATAX), one gets:

$$
M T V_{t}=\left(\min A T A X_{t+j}\right)-\left(A T A X_{t}\right) \quad \text { with } j=1 \ldots(\bar{L}-L) .
$$

Again, both $(R) M C V$ and $M T V$ measures indicate that the higher the difference between future and current costs (taxes) comprised in the decision of retirement, the more likely individuals will tend to postpone the year of retirement. Finally, I will compare the above parameters with the existing Peak Value proposed by Coile and Gruber (2000a), defined as the difference between the Maximum future expected SS Wealth and the current one, and the Option Value of delayed retirement by Stock and Wise (1990) ${ }^{7}$.

Finally, the replacement Ratio $(R R)$ is defined as the ratio of the first pension to the last wage and can be considered a "short-sight" indicator; however one must bear in mind that the interpretation above is a simplification, in that the $R R$ represents also the desired standard of living for the future and, thus, it probably comes out of some optimization process of smoothing consumption over time. In the remainder of the work I will refer to SSW and to RR as "static incentives" and to the others as "dynamic incentives". Among the latter, I will discriminate between "one-year dynamic" and "lifetime" measures, including the (R)MCR, Accrual, Tax/Subsidy in the former subset and the Peak Value (PV), (R)MCV, the OV and the MTV in the latter.

\section{Data and empirical strategy}

The Data comes from the Survey on Italian Households' Income and Wealth, carried out by the Bank of Italy every two years. It involves about 8000 households, representative of Italian population, and since 1989 a partially rotating panel (consisting of about $1 / 3$ of the whole sample) is provided as well, with increasing numerical dimension through years. At the moment 5 waves (from 1989 up to 1998) are publicly available. In this study I select male individuals who were employed householders (or head's partners) belonging to the panel component, 
being both interviewed in two or more waves through 1995 and aged from 48 to 64: notice that the choice of age 64 is due to the fact that retirement at age 65 was compulsory. Moreover, by exploiting some retrospective information (about retirement, family composition) I can built up a sample of person-year observations which includes also years not covered directly by interviews (see Spataro (2002) for a detailed explanation of sample building-up strategy).

The sample is constructed conditional on being at work or having retired in the year. I exclude selfemployed individuals since they have been subject to substantially different SS rules, individuals who were still working after a previous retirement and those retired prior to being eligible, that is due to special laws, often used in Italy for income assistance in favor of older workers at risk of unemployment ("pre-pensionamenti"). As a result the original 1065 panel workers and 2129 original person-year data are converted into 4283 person-year observations by creating new records for each period not covered but adjacent to the interview year.

The estimation strategy is particularly complex, in that, first of all, wages reported in the Survey are net of taxes, while the formula of pension benefits requires pre-taxes wages; secondly, we need both retrospective and future wages: the former are necessary for computing the "pensionable earnings"; the latter are needed to calculate forward-looking SS incentives. Finally, contributions paid to the National Fund are provided only in 1995 SHIW interviews, while the opportunity cost of retirees (i.e. the current year wage) has to be completely imputed. In order to overcome these problems I gross up wages by using information about tax rates and releases due to family composition; Then, I impute both wages (past and future) and contributions to my sample after OLS estimations over the whole 1989-1995 and 1995 cross sections, respectively. I also correct the composition effect for wages by using Heckman's two-steps procedure: in other words, wages are "purged" from the "selectivity bias" by conditioning the wage equation on the probability of being at work; for contributions estimates such correction was not necessary since the latter distortion did not turn out to be significant under different specifications of the selection equation and both using maximum likelihood or two-steps estimators ${ }^{8}$.

\section{Results}

Results are presented separately for Public and Private Sector median workers and according to whether the period considered is prior to reforms or not and to whether they are static or dynamic. Introductorily, let us firstly look at Table 2a: the first row of the second column contains the SSW provided by the SS system in case the individual retires on his $48^{\text {th }}$ birthday. Similarly, as for the "dynamic incentives", the RMCR column represents the yearly cost faced by an individual contrasting the possibility of leaving the labor force at the age labeled in the first row or at one year later. All values are expressed in 1992 thousand Italian lira.

\subsection{SS incentives prior to reforms}

For Public Sector employees, the first relevant finding is that eligibility constraints are binding for only $21 \%$ of the sample (see Total Observations in Table 2a), so that both quantitative and qualitative differences between eligible and not eligible workers' incentives turn out to be negligible: for this reason I will mainly comment results stemming from the whole sample of State workers and will discuss those of eligible workers only when significantly different.

Starting from the static incentives, the SSW keeps substantially constant through age 53, then declines through age 60: this means that in this age interval the increase in the pension level due to the postponement of retirement by one year is offset by the "time effect", that is by the reduction of the time-span in which such accrued wealth can be consumed. Notice that, as for eligible workers, the drop in the SSW value by age 60 is less dramatic and that SSW rises again only after age 61: clearly this feature is due to the effect of binding eligibility constraints. The overall median RR provided by SS in years 1988-1992 is about 67\% of the last wage and is upward sloped only through age 56 ( 57 for eligible workers): this feature may be caused by the fact that individuals are different along time (some of them enter the panel, other exit for some reason) and by a cohort effect (or selectivity bias), so that most individuals who are still at work by their 60s are likely to have completed less payment years to the SS National Fund and, thus, would obtain lower pension benefits; in any case, the negative values of the Accruals do appear consistent with the SSW age pattern. 
Turning to the other "dynamic one-year measures", I will focus on the features of RMCR, in order to illuminate its properties both on intuitive and coherence-with-economic-theory grounds. The first worth noting result is the fact that the RMCR is significantly less then one throughout the age interval under investigation: this means that for an individual aged, say, 54, the actual loss comprised in the choice of retirement at the beginning of the year instead of postponing it by one year, would be about $35 \%$ of the current wage (less than $18 \%$ for the median eligible worker aged 54). This finding (together with the high positive value of the implicit tax/subsidy rate) confirms the presence of a high "tax" (around 70\% of the current wage for the median worker) over continued work. However, the steadily decreasing pattern of the RMCR also seems to indicate the possible presence of a (weak) dynamic incentive to postpone retirement, since it becomes less costly to delay the exit from work as the median individual ages. Another interesting finding is the negative sign of the RMCR starting from age 59, for both eligible and the whole Public Sector employee sample: this means that the median worker aged 59 was provided with a subsidy for retirement 1,03 times as high as his current year wage. The reasons for the negative sign are possibly threefold: the already mentioned actuarial unfairness of the benefit formula, the decrease in wages by the end of the age interval, which progressively reduces the pension increase and, finally, the 40 year-contribution limit for pension computation.

Looking at the "lifetime" measures of SS incentives, reported in the first four columns of Table 3, results do not seem to change significantly": in fact I get negative, substantially decreasing PVs, reaching the minimum values by age 60 . However, on can infer additional information by looking at the other measures: although with the same negative trend and the age 48 maximum/age 61 minimum, the OV keeps positive till age 58 and has two other peaks at age 52-53; in turn, and maybe more interestingly, the shape of the RMCV distribution reveals the presence of some relative incentive to retirement at ages 51-54 age (as confirmed by the spikes occurring at these ages, which however take on negative values). This SS measure reaches the maximum at age 61, when the difference between future and present MCR is about -0.12. Yet, notice that negative sign of the RMCV for median workers of all ages (and even for those older than 60) confirms that the longitudinal shape of the MCR is downward sloped, at least for some future age interval. This finding is supported also by the corresponding lifetime incentive of the (negative of the) Accruals, the MTV: in fact it documents that the difference between the minimum of the expected tax levied on anticipated retirement and the current year value is negative throughout the whole age interval, meaning that for the median individual there is at least one year in the future in which such "tax" on retirement is lower than the present one. In the light of the findings above I can conclude that both static and dynamic incentive measures reveal a strong discouragement of continued work, which, however, might have been mitigated by the offsetting effect of negative RMCVs and MTVs.

As for Private Sector employees, statistics reported in Table $2 \mathrm{~b}$ show that eligibility rules have played a relevant role in determining the shape of SS incentives. In fact, I document a strong non-linearity in the SS incentives pattern due to binding eligibility constraints, since the majority of workers younger than 60 are constrained on contribution-requirement grounds, so that only $17 \%$ of them turn out to be eligible for claiming pension benefits ( $21 \%$ out of overall Private Sector employees). Clearly this feature is responsible for the relevant non-monotonicity of the SS incentive shapes occurring by age 59. This also can explain why the median RR is zero for all median workers aged less than 60 and why the SSW keeps constant throughout the same age interval and equal to the discounted present value of the sum of the minimum benefit flow attainable after age 65. (Notice that median Accruals are positive due to the indexation of the such "minimum benefits"). Finally, also the RMCR keeps constant through age 59 and approximately equal to the fraction of the current wage available after SS tax payment. According to this scenario, it clearly emerges that SS matters in retirement decisions, at least for eligibility reasons; in any case, after age 60, where eligibility requirement are mostly non-binding, the decision to postpone the exit from labor force by one year becomes very costly: in fact beyond that age the RMCR comprised in the choice of retiring by the current year instead of by the next is very high.

As for eligible workers, it is worth noting that RR values are, in general, lower than those provided to Public Sector employees: this is due to the relatively less favorable rules for pension computation; moreover, the non-linearities in the SS incentives (for example, the positive value of the Accrual at age 51), are plausibly to be imputed to a composition affect, in that individuals who are eligible at very young ages (and in the first years of the sample) contribute to the increase of the median (say, RRs) values until they retire and/or exit the panel. 
The "lifetime" incentives labeled in Table 3 confirm the role played by the combination of the contribution requirement/normal age eligibility rules: in fact, by focusing on the whole Private Sector sub-sample we can observe that both the $P V$ and the $O V$ strongly decrease, even changing the sign, at the $60^{\text {th }}$ birthday of the median worker. In any case, as for eligible individuals, while the $P V$ is always negative (with the exception of individuals aged 49-51 and although slightly increasing through age 58), the positive OV values document the existence of incentives to postpone retirement up to age 60 . The same positive reward of postponing retirement in future years is confirmed by the negative sign of the $R M C V$ and of the $M T V$ measures: notice that the range of variation of the latter parameters is higher and that their time pattern unveils non-linearities at age 51, 59 and 63 (also 54 and 62 for the $M T V)^{10}$. Concluding, also (eligible) Private Sector employees turn out to have been provided with generous, incentives for early retirement, although mitigated by the effect shown by some of the lifetime measures.

\subsection{SS incentives after reforms}

In Table 5 the variation rates of SS incentive measures are reported for period 1993-1995. For the sake of comparability I focus on those individuals who were eligible both before and after reforms. In fact the major restriction has been the temporary halt to early retirement (that is retirement with less than 35 year of contribution payment) imposed by the Government in years 1993 and 1995: as a consequence, the number of Public Sector individuals entitled with a State pension almost halved. According to the computations the SSW level of eligible workers has decreased dramatically due to such reforms: by about $20 \%$ and $18.5 \%$ for Public and Private Sector employees respectively; the main cut has been the reduction of the benefit indexation started in 1993. In fact both 1993 and 1995 reforms were phased in only gradually, so that the cut of benefits was designed to affect younger cohorts in the first place (see Table 4 for a summary of the most relevant changes): this is the main explanation of the heavier reduction of SSW undergone by younger cohorts. Accruals lowered by $15-16 \%$ and very similar was the reduction of the Peak Value. Results appear less straightforward when one looks at the changes of other dynamic parameters. On the one hand, although the median RMCR fell down for both eligible Public and Private Sector employees, the magnitude of such changes are quite different: a $45 \%$ reduction for the former and only $4.4 \%$ for the latter, respectively. Moreover, as for the RMCV, the signs of the overall variation diverge, even though the range of its changes is small (-3.2\% an 3.8\% respectively). On the other hand, the MTV measures decreased by about $15 \%$ for both categories. A possible explanation of these differences might by the following: both categories experienced major reductions of SS benefits, so that the future cost of retirement has increased, but Public Sector employees underwent the strongest cuts (due to the relatively higher impact of changes on the pensionable earnings formula, the introduction of wage caps and, perhaps more importantly, the penalization on early retirement by means of actuarial adjustment of pension levels introduced in the transitional phase). Consequently, for State employees it resulted economically convenient to delay the choice of retirement by some years after reforms. In other words, the median worker employed in the Public Sector could compensate the reduction of his pension entitlements by prosecuting his activity. On the contrary, for the other working category, the reforms, although lowering the level of the static incentives (such as SSW) had little impact on the dynamic incentives (both one year and lifetime), whose main source of variation has probably been the rise of SS payroll taxes.

Finally, significant non-monotonicities in the pattern of SS incentives changes are worth noting: this feature, again, can be explained by recalling that reforms in the transitional phase where conceived to produce effects inversely correlated with seniority (for example, a few pension cuts did not apply to individuals who had completed 40 years of payment to the National Fund); in fact this explanation seems to be coherent also with the high non-linearities in the changes of both the RMCR and the RMVC shown by the State eligible workers: to put it differently, given the less restrictive eligibility requirements enjoyed by latter employees, it is plausible that their higher heterogeneity in the years of contribution payments is mostly responsible for the higher variability that the effects of the reforms show for this working sector.

\section{Conclusions}

In the present work I compute the SS incentives to early retirement enjoyed by Italian male employees during the late 80s and early 90s. The contribution I propose is twofold: firstly, I use the 1989-1995 panel provided by bank of Italy Survey (SHIW), thus complementing the previous works which either have been merely theoretical 
(i.e. based on simulations of representative workers) or used different data sources (such as the National Fund (INPS) archive, which however covers Private Sector employees only). Secondly, I set up three new measures of "dynamic incentives": the first is called the Marginal Cost of Retirement (MCR) and, although very close to already existing parameters, clarifies the economic nature of the cost comprised in the choice of anticipating retirement by one year. Moreover, it has the property of providing an exact and intuitive measure of the tax/subsidy on prosecuted work brought about by the actuarial unfairness of the pension formula; finally, the rescaled version of the MCR allows for strongly reducing the correlation of this parameter with the current wage. The second new measure is the Minimum Cost Value (MCV), which is a lifetime extension of the MCR: precisely, it is the difference between the minimum expected MCR in any future year and the current MCR. Finally, by the same reasoning, a "lifetime" version of the (negative of the) Accruals is proposed (referred to as the Minimum Tax Value, (MTV)).

Results show that, first of all, it is necessary to discriminate between Public and Private Sector, since eligibility rules, benefit computation formula (more favorable for the latter) and reform impacts have been substantially different for these categories of workers. Secondly, I do find evidence of strong incentives for early retirement for Public Sector employees before reforms. In fact for such workers the SSW was substantially decreasing with respect to age; moreover, the one-year dynamic incentives confirm the relevant "tax" levied on the prosecution to work provided by SS system prior to reforms: in fact the median RMCR was abundantly less than 1 (about 29\% of current salary) and decreasing for almost all ages. As for the Private Sector workers, computations show that the contribution requirement for retirement eligibility has been binding for the majority of Private Sector workers; this notwithstanding, it comes out that also such workers enjoyed strong (one-year dynamic) incentives to retire once the normal age (age 60) had been reached. However, some of the lifetime dynamic measures (particularly the negative values of both RMCV and MTV for both Sectors) reveal the presence of incentives for postponing retirement which may have been contrasting (or even offsetting) the impact of the former.

Finally, early 1990s reforms reduced the median SSW by about $20 \%$ and the median Peak Value by almost 19\%; however, among eligible workers, Public Sector employees appear to have borne most of the burden of the benefit cuts, particularly due to the higher penalizations on early retirement. There also comes out that younger cohorts have been and will be more dramatically in the future the net-payers for the rebalance of the Italian SS system. In fact, both the generous pre-reform benefits and the reduction of the RMCV and MTVs occurred in the transition phase of reforms has provided the older cohorts with a substantial incentives for exiting the labor force.

\section{References}

1. Aaron H. (1966) "The Social Insurance Paradox", Canadian Journal of Economics and Political Science, vol XXXII, n.3.

2. $\quad$ Banca d'Italia: I Bilanci delle Famiglie Italiane negli Anni 1977-1995. Supplementi al Bollettino Statistico (Note Metodologiche ed Informazioni Statistiche), several years

3. Blondal S. and Scarpetta S. (1998) "The Retirement decision in OECD Countries", AWP 1.4, OECD, Paris.

4. Bosi P. (1995) "Un punto di vista macroeconomico sulle caratteristiche di lungo periodo del nuovo sistema pensionistico italiano", Politica Economica 11(3): 325-56.

5. Bosi P. (1997) "Aumentare l'età pensionabile fa diminuire la spesa pensionistica? Ancora sulle caratteristiche di lungo periodo della riforma Dini", Politica Economica 13(2): 295-304.

6. Breyer F. and Straub M. (1993) "Welfare Effects of Unfunded Pension Systems When Labor Supply Is Endogenous", Journal of Public Economics 50(1): 77-91.

7. Brugiavini A. (1999) "Social Security and Retirement in Italy", in Gruber J e Wise D (edited by): Social security and retirement around the world. NBER Conference Report series. Chicago and London: University of Chicago Press.

8. Brugiavini A. and Peracchi F. (2001) "Micro Modeling of Retirement Behavior in Italy", prepared for the Workshop: "Socio-demographic factors and the future of the welfare state in Italy", March, Frascati (Rome), mimeo.

9. Casarosa C. (1996) "Alcune semplici relazioni fra sistema previdenziale, vincolo distributivo, occupazione e disoccupazione", Rivista di Politica Economica 86(7-8): 27-60. 
10. Castellino O. (1995) "Redistribution Between and Within Generations in the Italian Social Security System", Ricerche Economiche 49(4): 317-327.

11. Coile C. and Gruber J. (2000a): "Social Security Incentives for Retirement", NBER WP. No. 7651.

12. Coile C. and Gruber J. (2000b): "Social Security and Retirement", NBER WP. No. 7830.

13. Colombino U. (2002) "A Simple Intertemporal Model of Retirement Estimated on Italian Cross-Section Data", mimeo.

14. Ferraresi P.M. and Fornero E.(2000) "Costi e distorsioni della transizione previdenziale ed effetti correttivi di alcune ipotesi di riforma", Politica Economica, Aprile, 1: 3-47.

15. Greene W.H. (1999) Econometric analysis, IV edition, New York, Prentice Hall.

16. Gronchi S. (1995) "Previdenza, riforma minata", Il Sole 24Ore, 30 giugno.

17. Gustman A.L. and Steinmeier (1986) "A structural Retirement Model”, Econometrica, 54(3): 555-584

18. Hu S.C. (1979) "Social Security, the Supply of Labor, and Capital Accumulation", American Economic Review 69(3): 274-83.

19. ISTAT (1997) "Previsioni della popolazione residente per sesso, età e regione, base 1.1.1996", Collana Informazioni, n. 34.

20. Miniaci R. (1998) "Microeconometric Analysis of the Retirement Decision: Italy". OECD Economics Department W.P. No. 205, Parigi.

21. Onofri P. (1998): "Nonostante tutto, un altro pezzo di riforma del sistema pensionistico", Politica Economica, 14(1): 5-19.

22. Rust J. and Phelan C. (1997) "How Social Security and Medicare Affect Retirement Behavior in a World of Incomplete Markets". Econometrica 65(4): 781-831.

23. Samwick A. (1998) "New evidence on Pensions, Social Security, and the Timing of Retirement, NBER WP No. 6534.

24. Spataro L. (2000) "Le scelte di pensionamento in Italia: un'applicazione (ed estensione) del modello Option Value"; Studi Economici, 72: 25-54.

25. Spataro L. (2002) "Social Security and Retirement Decisions in Italy", mimeo.

26. Vitaletti G. (2000) "Problemi e potenzialità della riforma pensionistica del 1995 in un confronto tra modelli previdenziali stilizzati”, Economia Pubblica, n.4.

Table 1: Sample for the analysis

\begin{tabular}{|c|c|c|c|c|}
\hline Year & \multicolumn{4}{|c|}{ Original Observations } \\
\hline & Public Sector & Private Sector & Public Sector & Private Sector \\
\hline & & & 162 & 162 \\
\hline 88 & 158 & 157 & 158 & 157 \\
\hline 89 & & & 333 & 335 \\
\hline 90 & 334 & 345 & 334 & 345 \\
\hline 91 & 321 & 325 & 321 & 328 \\
\hline 92 & & & 321 & 325 \\
\hline 93 & 262 & 227 & 273 & 240 \\
\hline 94 & 1075 & 1054 & 262 & 227 \\
\hline 95 & & & 2164 & 2119 \\
\hline Total & & & & \\
\hline
\end{tabular}


Tab 2a: Static and one-year dynamic SS incentives:

Medians by age (Public Sector employees, years 1988-1992). Std. Dev. in parentheses

\begin{tabular}{|c|c|c|c|c|c|c|c|c|c|c|c|c|}
\hline \multirow[b]{2}{*}{ Age } & \multicolumn{6}{|c|}{ Whole sample } & \multicolumn{6}{|c|}{ Eligible workers } \\
\hline & Obs & SSW* & Accrual* & SS Tax & RMCR & $\mathbf{R R}$ & Obs & SSW* & Accrual* & SS Tax & RMCR & RR \\
\hline 48 & 96 & \begin{tabular}{|l|}
570276.2 \\
$(252360.5)$ \\
\end{tabular} & \begin{tabular}{|l|}
-2191.9 \\
$(95347.5)$ \\
\end{tabular} & $\begin{array}{l}.063 \\
(2.30) \\
\end{array}$ & \begin{tabular}{|l|}
697 \\
$(2.29)$ \\
\end{tabular} & \begin{tabular}{|l|}
.574 \\
$(.27)$ \\
\end{tabular} & 72 & \begin{tabular}{|l|l|}
603744.5 \\
$(220983.2)$ \\
\end{tabular} & \begin{tabular}{|l|}
-8502.9 \\
$(45948.1)$ \\
\end{tabular} & \begin{tabular}{|l|}
.216 \\
$(1.17)$ \\
\end{tabular} & \begin{tabular}{|l|}
.549 \\
$(1.13)$ \\
\end{tabular} & \begin{tabular}{|l|}
.615 \\
$(.07)$ \\
\end{tabular} \\
\hline 49 & 106 & \begin{tabular}{|l|}
584969.4 \\
$(217099.8)$ \\
\end{tabular} & \begin{tabular}{|l|}
-1207.5 \\
$(44840.8)$ \\
\end{tabular} & $\begin{array}{l}.037 \\
(1.36) \\
\end{array}$ & \begin{tabular}{|l|}
.714 \\
$(1.34)$ \\
\end{tabular} & \begin{tabular}{|l|}
.572 \\
$(.28)$ \\
\end{tabular} & 78 & \begin{tabular}{|l|l|}
580024.2 \\
$(184934.6)$ \\
\end{tabular} & \begin{tabular}{|l|}
-2982.78 \\
$(16719.9)$ \\
\end{tabular} & \begin{tabular}{|l|}
.091 \\
$(.85)$ \\
\end{tabular} & \begin{tabular}{|l|}
.668 \\
$(.81)$ \\
\end{tabular} & \begin{tabular}{|l|}
.623 \\
$(.07)$ \\
\end{tabular} \\
\hline 50 & 116 & $\begin{array}{l}581885.8 \\
(196524.7)\end{array}$ & \begin{tabular}{|l|}
-7016.2 \\
$(11902.7)$
\end{tabular} & $\begin{array}{l}.248 \\
(.42)\end{array}$ & $\begin{array}{l}.510 \\
(.40) \\
\end{array}$ & $\begin{array}{l}.621 \\
(.30) \\
\end{array}$ & 83 & \begin{tabular}{|l|}
599081.2 \\
$(189291.1)$
\end{tabular} & \begin{tabular}{|l|}
-5909.2 \\
$(13646.3)$ \\
\end{tabular} & $\begin{array}{l}.244 \\
(.48)\end{array}$ & \begin{tabular}{|l|}
.517 \\
$(.46)$ \\
\end{tabular} & $\begin{array}{l}.668 \\
(.08) \\
\end{array}$ \\
\hline 51 & 106 & \begin{tabular}{|l|}
577468.7 \\
$(249805.8)$ \\
\end{tabular} & \begin{tabular}{|l|}
-10048.8 \\
$(23271.8)$ \\
\end{tabular} & $\begin{array}{l}.322 \\
(.50) \\
\end{array}$ & \begin{tabular}{|l|}
.438 \\
$(.48)$ \\
\end{tabular} & \begin{tabular}{|l|}
.635 \\
$(.28)$ \\
\end{tabular} & 84 & \begin{tabular}{|l|}
603286 \\
$(228201.3)$ \\
\end{tabular} & \begin{tabular}{|l|}
-10831.5 \\
$(25219.9)$ \\
\end{tabular} & \begin{tabular}{|l}
.356 \\
$(.53)$ \\
\end{tabular} & \begin{tabular}{|l|}
.408 \\
$(.51)$ \\
\end{tabular} & \begin{tabular}{|l|}
.672 \\
$(.07)$ \\
\end{tabular} \\
\hline 52 & 107 & $\begin{array}{l}547934.6 \\
(227425.9)\end{array}$ & \begin{tabular}{|l|}
-9267.0 \\
$(34315.1)$ \\
\end{tabular} & $\begin{array}{l}.317 \\
(1.07)\end{array}$ & \begin{tabular}{|l|}
.444 \\
$(1.05)$ \\
\end{tabular} & $\begin{array}{l}.650 \\
(.27) \\
\end{array}$ & 87 & \begin{tabular}{|l|}
541168.8 \\
$(215917.7)$ \\
\end{tabular} & \begin{tabular}{|l|}
-9065.8 \\
$(31308.4)$ \\
\end{tabular} & $\begin{array}{l}.303 \\
(.79) \\
\end{array}$ & \begin{tabular}{|l|}
.454 \\
$(.76)$ \\
\end{tabular} & $\begin{array}{l}.666 \\
(.07) \\
\end{array}$ \\
\hline 53 & 92 & $\begin{array}{l}562312.8 \\
(271981) \\
\end{array}$ & \begin{tabular}{|l|}
-14119.4 \\
$(36964.6)$ \\
\end{tabular} & $\begin{array}{l}.398 \\
(1.13) \\
\end{array}$ & $\begin{array}{l}.363 \\
(1.12) \\
\end{array}$ & \begin{tabular}{|l}
.685 \\
$(.29)$ \\
\end{tabular} & 73 & \begin{tabular}{|l|}
570825.9 \\
$(237971.2)$
\end{tabular} & \begin{tabular}{|l|}
-14237.4 \\
$(28036.2)$ \\
\end{tabular} & $\begin{array}{l}.407 \\
(.70) \\
\end{array}$ & \begin{tabular}{|l|}
.356 \\
$(.67)$ \\
\end{tabular} & $\begin{array}{l}.713 \\
(.08) \\
\end{array}$ \\
\hline 54 & 97 & $\begin{array}{l}558205.1 \\
(240992.2)\end{array}$ & \begin{tabular}{|l|}
-13879.6 \\
$(47484.1)$ \\
\end{tabular} & $\begin{array}{l}.424 \\
(1.54)\end{array}$ & \begin{tabular}{|l|}
346 \\
$(1.53)$ \\
\end{tabular} & $\begin{array}{l}.676 \\
(.32) \\
\end{array}$ & 71 & \begin{tabular}{|l|}
564407.8 \\
$(228303)$ \\
\end{tabular} & \begin{tabular}{|l|}
-17681.6 \\
$(32346.6)$ \\
\end{tabular} & $\begin{array}{l}.615 \\
(.66) \\
\end{array}$ & \begin{tabular}{|l|}
.177 \\
$(.63)$ \\
\end{tabular} & \begin{tabular}{|l|}
.710 \\
$(.09)$ \\
\end{tabular} \\
\hline 55 & 99 & $\begin{array}{l}528356.8 \\
(234199.1) \\
\end{array}$ & \begin{tabular}{|l|}
-11638.3 \\
$(45392.1)$ \\
\end{tabular} & $\begin{array}{l}.430 \\
(1.12)\end{array}$ & \begin{tabular}{|l|}
.327 \\
$(1.08)$ \\
\end{tabular} & \begin{tabular}{|l|}
.701 \\
$(.27)$ \\
\end{tabular} & 84 & \begin{tabular}{|l|}
530286.4 \\
$(233303.5)$ \\
\end{tabular} & \begin{tabular}{|l|}
-10602.9 \\
$(47515.7)$ \\
\end{tabular} & \begin{tabular}{|l|}
.397 \\
$(1.02)$ \\
\end{tabular} & \begin{tabular}{|l|}
.359 \\
$(.98)$ \\
\end{tabular} & \begin{tabular}{|l|}
.714 \\
$(.09)$ \\
\end{tabular} \\
\hline 56 & 97 & \begin{tabular}{|l|}
534873.6 \\
$(237526.3)$ \\
\end{tabular} & \begin{tabular}{|l|}
-14593.5 \\
$(22654.4)$ \\
\end{tabular} & $\begin{array}{l}.499 \\
(.55) \\
\end{array}$ & \begin{tabular}{|l|}
.263 \\
$(.53)$ \\
\end{tabular} & \begin{tabular}{|l|}
.721 \\
$(.30)$ \\
\end{tabular} & 78 & \begin{tabular}{|l|}
528577.5 \\
$(220125.1)$ \\
\end{tabular} & \begin{tabular}{|l|}
-14363.8 \\
$(24837.3)$ \\
\end{tabular} & \begin{tabular}{|l|}
.498 \\
$(.60)$ \\
\end{tabular} & \begin{tabular}{|l|}
.263 \\
$(.58)$ \\
\end{tabular} & \begin{tabular}{|l|}
.735 \\
$(.09)$ \\
\end{tabular} \\
\hline 57 & 87 & $\begin{array}{l}490100.3 \\
(257528.1) \\
\end{array}$ & \begin{tabular}{|l|}
-14849.0 \\
$(27565.6)$ \\
\end{tabular} & $\begin{array}{l}.507 \\
(.99) \\
\end{array}$ & \begin{tabular}{|l|}
.250 \\
$(.98)$ \\
\end{tabular} & \begin{tabular}{|l|}
.713 \\
$(.31)$ \\
\end{tabular} & 69 & \begin{tabular}{|l|}
509579.7 \\
$(241148.6)$ \\
\end{tabular} & \begin{tabular}{|l|}
-17059.5 \\
$(21866.4)$ \\
\end{tabular} & $\begin{array}{l}.546 \\
(.73) \\
\end{array}$ & \begin{tabular}{|l|}
.223 \\
$(.70)$ \\
\end{tabular} & \begin{tabular}{|l|}
.750 \\
$(.09)$ \\
\end{tabular} \\
\hline 58 & 67 & \begin{tabular}{|l|}
493828.6 \\
$(232980.5)$ \\
\end{tabular} & \begin{tabular}{|l|}
-21512.3 \\
$(19806.2)$ \\
\end{tabular} & $\begin{array}{l}.623 \\
(.55) \\
\end{array}$ & \begin{tabular}{|l|}
.152 \\
$(.53)$ \\
\end{tabular} & \begin{tabular}{|l|}
.684 \\
$(.27)$ \\
\end{tabular} & 57 & \begin{tabular}{|l|l|}
485862.6 \\
$(222464.4)$ \\
\end{tabular} & \begin{tabular}{|l|}
-20099.2 \\
$(19427.8)$ \\
\end{tabular} & \begin{tabular}{|l}
.602 \\
$(.54)$ \\
\end{tabular} & \begin{tabular}{|l|}
.166 \\
$(.51)$ \\
\end{tabular} & \begin{tabular}{|l|}
.720 \\
$(.08)$ \\
\end{tabular} \\
\hline 59 & 60 & $\begin{array}{l}458684.1 \\
(200150.9) \\
\end{array}$ & \begin{tabular}{|l|}
-26381.1 \\
$(16648.6)$ \\
\end{tabular} & $\begin{array}{l}.806 \\
(.65) \\
\end{array}$ & \begin{tabular}{|l|}
-.034 \\
$(.64)$ \\
\end{tabular} & \begin{tabular}{|l|}
.693 \\
$(.26)$ \\
\end{tabular} & 51 & \begin{tabular}{|l|}
460892.3 \\
$(194222.6)$ \\
\end{tabular} & \begin{tabular}{|l|}
-26740.5 \\
$(11868.9)$ \\
\end{tabular} & \begin{tabular}{|l|}
.846 \\
$(.34)$ \\
\end{tabular} & \begin{tabular}{|l|}
-.062 \\
$(.33)$ \\
\end{tabular} & \begin{tabular}{|l|}
.702 \\
$(.08)$ \\
\end{tabular} \\
\hline 60 & 55 & $\begin{array}{l}394232.9 \\
(182656.4)\end{array}$ & \begin{tabular}{|l|}
-28078.6 \\
$(29994.7)$ \\
\end{tabular} & $\begin{array}{l}1.001 \\
(.78) \\
\end{array}$ & \begin{tabular}{|l|}
-.211 \\
$(.74)$ \\
\end{tabular} & \begin{tabular}{|l|}
.657 \\
$(.34)$ \\
\end{tabular} & 37 & \begin{tabular}{|l|}
433376.5 \\
$(166357.7)$ \\
\end{tabular} & \begin{tabular}{|l|}
-26526.2 \\
$(33604.6)$ \\
\end{tabular} & \begin{tabular}{|l|}
.930 \\
$(.86)$ \\
\end{tabular} & \begin{tabular}{|l|}
-.153 \\
$(.81)$ \\
\end{tabular} & \begin{tabular}{|l|}
.706 \\
$(.09)$ \\
\end{tabular} \\
\hline 61 & 39 & $\begin{array}{l}401932.3 \\
(243315.3) \\
\end{array}$ & \begin{tabular}{|l|}
-32116.7 \\
$(48778.4)$ \\
\end{tabular} & $\begin{array}{r}1.120 \\
(.98) \\
\end{array}$ & \begin{tabular}{|l}
.322 \\
$(.94)$ \\
\end{tabular} & \begin{tabular}{|l|}
.712 \\
$(.24)$ \\
\end{tabular} & 35 & \begin{tabular}{|l|l|}
414990.4 \\
$(243573.8)$
\end{tabular} & \begin{tabular}{|l|}
-37891.9 \\
$(50865.6)$ \\
\end{tabular} & $\begin{array}{l}1.136 \\
(1.01)\end{array}$ & \begin{tabular}{|l|}
.350 \\
$(.96)$ \\
\end{tabular} & \begin{tabular}{|l|}
.722 \\
$(.09)$ \\
\end{tabular} \\
\hline 62 & 36 & $\begin{array}{l}446296.5 \\
(239200.4)\end{array}$ & \begin{tabular}{|l|}
-27195.3 \\
$(36361.1)$ \\
\end{tabular} & $\begin{array}{l}1.073 \\
(.74) \\
\end{array}$ & \begin{tabular}{|l}
-.278 \\
$(.71)$ \\
\end{tabular} & $\begin{array}{l}.711 \\
(.31) \\
\end{array}$ & 29 & \begin{tabular}{|l|}
438466.3 \\
$(241856.1)$ \\
\end{tabular} & \begin{tabular}{|l|}
-34649.2 \\
$(36289.5)$ \\
\end{tabular} & $\begin{array}{l}1.132 \\
(.65) \\
\end{array}$ & \begin{tabular}{|l|}
-.345 \\
$(.62)$ \\
\end{tabular} & $\begin{array}{l}.735 \\
(.10) \\
\end{array}$ \\
\hline 63 & 28 & $\begin{array}{l}413200.4 \\
(278127.8) \\
\end{array}$ & \begin{tabular}{|l|l|}
-29326.2 \\
$(58893.3)$ \\
\end{tabular} & $\begin{array}{l}.922 \\
(2.23)\end{array}$ & \begin{tabular}{|l|}
-.148 \\
$(2.12)$ \\
\end{tabular} & \begin{tabular}{|l|}
.775 \\
$(.11)$ \\
\end{tabular} & 28 & \begin{tabular}{|l|l|}
413200.4 \\
$(278127.8)$ \\
\end{tabular} & \begin{tabular}{|l|}
-29326.2 \\
$(58893.3)$ \\
\end{tabular} & \begin{tabular}{|l|}
.922 \\
$(2.23)$ \\
\end{tabular} & \begin{tabular}{|l|}
-.148 \\
$(2.12)$ \\
\end{tabular} & \begin{tabular}{|l|}
.775 \\
$(.11)$ \\
\end{tabular} \\
\hline 64 & 20 & $\begin{array}{l}318238.7 \\
(219946.2) \\
\end{array}$ & \begin{tabular}{|l|}
-33958.3 \\
$(102743.8)$ \\
\end{tabular} & $\begin{array}{l}1.266 \\
(2.52) \\
\end{array}$ & \begin{tabular}{|l|}
-.447 \\
$(2.38)$ \\
\end{tabular} & \begin{tabular}{|l|}
.754 \\
$(.11)$ \\
\end{tabular} & 20 & \begin{tabular}{|l|}
318238.7 \\
$(219946.2)$ \\
\end{tabular} & \begin{tabular}{|l|}
-33958.3 \\
$(102743.8)$ \\
\end{tabular} & \begin{tabular}{|l|}
1.266 \\
$(2.52)$ \\
\end{tabular} & \begin{tabular}{|l|}
-.447 \\
$(2.38)$ \\
\end{tabular} & \begin{tabular}{|l|}
.754 \\
$(.11)$ \\
\end{tabular} \\
\hline Total & 1308 & $\begin{array}{l}531166.9 \\
(241353.6)\end{array}$ & $\begin{array}{l}-12352.09 \\
(45010.91)\end{array}$ & $\begin{array}{l}.425 \\
(1.24)\end{array}$ & $\begin{array}{r}.340 \\
(1.21)\end{array}$ & \begin{tabular}{|l}
.667 \\
$(.29)$ \\
\end{tabular} & 1036 & \begin{tabular}{|l|}
534376.9 \\
$(229628.6)$
\end{tabular} & \begin{tabular}{|l|}
-13810.3 \\
$(35660.8)$
\end{tabular} & $\begin{array}{l}.473 \\
(.94)\end{array}$ & $\begin{array}{l}.296 \\
(.90)\end{array}$ & $\begin{array}{l}.696 \\
(.09) \\
\end{array}$ \\
\hline
\end{tabular}

- $\quad$ (1992 lira divided by 10000) 


\begin{tabular}{|c|c|c|c|c|c|c|c|c|c|c|c|c|}
\hline \multirow[t]{2}{*}{ Age } & \multicolumn{6}{|c|}{ Whole sample } & \multicolumn{6}{|c|}{ Eligible workers } \\
\hline & Obs & SSW* & Accrual* & Tax-rate & RMCR & $\mathbf{R R}$ & Obs & SSW* & Accrual* & Tax-rate & RMCR & $\mathbf{R R}$ \\
\hline 48 & 139 & $\begin{array}{c}86996.02 \\
(171135.2)\end{array}$ & $\begin{array}{c}1266.656 \\
(76374.18)\end{array}$ & $\begin{array}{l}-.0446391 \\
(2.812407)\end{array}$ & $\begin{array}{c}.7981508 \\
(2.814776)\end{array}$ & $\begin{array}{c}0 \\
(.2333639)\end{array}$ & 19 & $\begin{array}{c}542558.1 \\
(135756.2)\end{array}$ & $\begin{array}{l}-22494.69 \\
(17537.67)\end{array}$ & $\begin{array}{c}.7282349 \\
(.7252873)\end{array}$ & $\begin{array}{c}.0456405 \\
(.7050376)\end{array}$ & $\begin{array}{c}.6983364 \\
(.0730111)\end{array}$ \\
\hline 49 & 135 & $\begin{array}{c}87345.76 \\
(119821.9)\end{array}$ & $\begin{array}{c}1310.188 \\
(131845.3)\end{array}$ & $\begin{array}{l}-.0470995 \\
(4.010884)\end{array}$ & $\begin{array}{c}.806577 \\
(4.009946)\end{array}$ & $\begin{array}{c}0 \\
(.1447157)\end{array}$ & 8 & $\begin{array}{c}456371.8 \\
(152172.5)\end{array}$ & $\begin{array}{c}1000.547 \\
(7137.909)\end{array}$ & $\begin{array}{l}-.0337448 \\
(.3954777)\end{array}$ & $\begin{array}{l}.7955966 \\
(.3855417)\end{array}$ & $\begin{array}{c}.5881642 \\
(.0569607)\end{array}$ \\
\hline 50 & 136 & $\begin{array}{c}87735.66 \\
(157867.9)\end{array}$ & $\begin{array}{c}1316.031 \\
(92578.14)\end{array}$ & $\begin{array}{l}-.0525749 \\
(3.179289)\end{array}$ & $\begin{array}{c}.8178064 \\
(3.179928)\end{array}$ & $\begin{array}{c}0 \\
(.1792241)\end{array}$ & 15 & $\begin{array}{c}485976 \\
(130272.6)\end{array}$ & $\begin{array}{c}1656.688 \\
(6306.435)\end{array}$ & $\begin{array}{c}-.0551416 \\
(.19893)\end{array}$ & $\begin{array}{c}.8101421 \\
(.2010753)\end{array}$ & $\begin{array}{c}.5593443 \\
(.0196567)\end{array}$ \\
\hline 51 & 139 & $\begin{array}{c}88163.6 \\
(169259.4)\end{array}$ & $\begin{array}{c}1283.648 \\
(123320.3)\end{array}$ & $\begin{array}{l}-.0539044 \\
(4.04594)\end{array}$ & $\begin{array}{c}.8233103 \\
(4.050728)\end{array}$ & $\begin{array}{c}0 \\
(.2001675)\end{array}$ & 17 & $\begin{array}{c}497570.5 \\
(125775.2)\end{array}$ & $\begin{array}{c}8741.063 \\
(20640.46)\end{array}$ & $\begin{array}{c}-.299233 \\
(.7562145)\end{array}$ & $\begin{array}{c}1.061564 \\
(.7430784)\end{array}$ & $\begin{array}{c}.5839171 \\
(.0513467)\end{array}$ \\
\hline 52 & 122 & $\begin{array}{c}88634.59 \\
(126752.1)\end{array}$ & $\begin{array}{c}1329.516 \\
(151273.8)\end{array}$ & $\begin{array}{l}-.0545503 \\
(4.346708)\end{array}$ & $\begin{array}{c}.8206824 \\
(4.347949)\end{array}$ & $\begin{array}{c}0 \\
(.2153458)\end{array}$ & 16 & $\begin{array}{c}420091.4 \\
(72648.73)\end{array}$ & $\begin{array}{l}-11838.05 \\
(22948.24)\end{array}$ & $\begin{array}{c}.431399 \\
(.9721853)\end{array}$ & $\begin{array}{l}.3286857 \\
(.9477434)\end{array}$ & $\begin{array}{c}.6097656 \\
(.0700263)\end{array}$ \\
\hline 53 & 119 & $\begin{array}{c}91848.48 \\
(188911.7)\end{array}$ & $\begin{array}{c}1298.07 \\
(100933.3)\end{array}$ & $\begin{array}{l}-.0449811 \\
(3.971569)\end{array}$ & $\begin{array}{c}.8067044 \\
(3.945018)\end{array}$ & $\begin{array}{c}0 \\
(.2530632)\end{array}$ & 24 & $\begin{array}{c}435131.4 \\
(159313.2)\end{array}$ & $\begin{array}{l}-16728.13 \\
(92305.46)\end{array}$ & $\begin{array}{l}.5546509 \\
(5.00594)\end{array}$ & $\begin{array}{l}.2147889 \\
(4.90123)\end{array}$ & $\begin{array}{c}.6146461 \\
(.0526817)\end{array}$ \\
\hline 54 & 97 & $\begin{array}{c}89732.9 \\
(175507.6)\end{array}$ & $\begin{array}{l}1306.508 \\
(135409)\end{array}$ & $\begin{array}{l}-.0543026 \\
(4.11977)\end{array}$ & $\begin{array}{c}.8144756 \\
(4.117726)\end{array}$ & $\begin{array}{c}0 \\
(.2965014)\end{array}$ & 26 & $\begin{array}{c}417554 \\
(115125)\end{array}$ & $\begin{array}{l}-19949.73 \\
(18596.33)\end{array}$ & $\begin{array}{c}.676736 \\
(.6938871)\end{array}$ & $\begin{array}{c}.092269 \\
(.6795089)\end{array}$ & $\begin{array}{c}.665283 \\
(.0521722)\end{array}$ \\
\hline 55 & 97 & $\begin{array}{c}93119.59 \\
(180287.2)\end{array}$ & $\begin{array}{c}1277.422 \\
(57620.54)\end{array}$ & $\begin{array}{l}-.0482433 \\
(2.14081)\end{array}$ & $\begin{array}{c}.8068368 \\
(2.139388)\end{array}$ & $\begin{array}{c}0 \\
(.2959351)\end{array}$ & 29 & $\begin{array}{c}388391.8 \\
(126115.6)\end{array}$ & $\begin{array}{l}-14990.88 \\
(14392.56)\end{array}$ & $\begin{array}{c}.5919914 \\
(.5073074)\end{array}$ & $\begin{array}{c}.1761159 \\
(.4909848)\end{array}$ & $\begin{array}{c}.6325566 \\
(.0607103)\end{array}$ \\
\hline 56 & 86 & $\begin{array}{c}91136.15 \\
(170182.9)\end{array}$ & $\begin{array}{c}1326.938 \\
(93440.32)\end{array}$ & $\begin{array}{l}-.0580499 \\
(3.25955)\end{array}$ & $\begin{array}{c}.8266801 \\
(3.257451)\end{array}$ & $\begin{array}{c}0 \\
(.2831346)\end{array}$ & 21 & $\begin{array}{c}383533.5 \\
(96428.95)\end{array}$ & $\begin{array}{c}-13427.56 \\
(19221.13)\end{array}$ & $\begin{array}{c}.5610456 \\
(.7038714)\end{array}$ & $\begin{array}{c}.2045872 \\
(.6880518)\end{array}$ & $\begin{array}{c}.6361234 \\
(.0606946)\end{array}$ \\
\hline 57 & 78 & $\begin{array}{c}91987.29 \\
(143433.5)\end{array}$ & $\begin{array}{c}1339.328 \\
(113132.8)\end{array}$ & $\begin{array}{l}-.0602063 \\
(2.779883)\end{array}$ & $\begin{array}{c}.8264536 \\
(2.776902)\end{array}$ & $\begin{array}{c}0 \\
(.2897086)\end{array}$ & 19 & $\begin{array}{c}356612.8 \\
(101992.7)\end{array}$ & $\begin{array}{l}-10457.28 \\
(18691.48)\end{array}$ & $\begin{array}{c}.443062 \\
(.8703077)\end{array}$ & $\begin{array}{c}.3289677 \\
(.8480099)\end{array}$ & $\begin{array}{c}.6524584 \\
(.0692422)\end{array}$ \\
\hline 58 & 53 & $\begin{array}{c}92947.69 \\
(153826.5)\end{array}$ & $\begin{array}{c}1353.313 \\
(76512.11)\end{array}$ & $\begin{array}{l}-.0611605 \\
(2.078593)\end{array}$ & $\begin{array}{c}.8400452 \\
(2.078382)\end{array}$ & $\begin{array}{c}0 \\
(.2497657)\end{array}$ & 10 & $\begin{array}{c}330580.4 \\
(205971.8)\end{array}$ & $\begin{array}{l}-6944.969 \\
(7519.468)\end{array}$ & $\begin{array}{c}.3126885 \\
(.1675417)\end{array}$ & $\begin{array}{l}.4562565 \\
(.1649171)\end{array}$ & $\begin{array}{l}.6124615 \\
(.0494384)\end{array}$ \\
\hline 59 & 40 & $\begin{array}{c}91268.76 \\
(103995.3)\end{array}$ & $\begin{array}{c}122024.2 \\
(123640.9)\end{array}$ & $\begin{array}{l}-6.122542 \\
(2.977769)\end{array}$ & $\begin{array}{c}6.867431 \\
(2.979212)\end{array}$ & $\begin{array}{c}0 \\
(.1941376)\end{array}$ & 4 & $\begin{array}{l}334956.8 \\
(144169)\end{array}$ & $\begin{array}{l}-8241.938 \\
(18780.86)\end{array}$ & $\begin{array}{c}.3421519 \\
(.8183873)\end{array}$ & $\begin{array}{l}.4352995 \\
(.8032988)\end{array}$ & $\begin{array}{c}.6133626 \\
(.0617695)\end{array}$ \\
\hline 60 & 42 & $\begin{array}{c}242354.3 \\
(121579.9)\end{array}$ & $\begin{array}{l}-13227.75 \\
(27232.45)\end{array}$ & $\begin{array}{l}.6292872 \\
(1.35556)\end{array}$ & $\begin{array}{c}.1545493 \\
(1.318282)\end{array}$ & $\begin{array}{c}.4995357 \\
(.2524005)\end{array}$ & 32 & $\begin{array}{c}243639 \\
(131381.7)\end{array}$ & $\begin{array}{l}-12827.59 \\
(28619.55)\end{array}$ & $\begin{array}{c}.61906 \\
(1.36615)\end{array}$ & $\begin{array}{c}.169289 \\
(1.321742)\end{array}$ & $\begin{array}{c}.5521789 \\
(.1169275)\end{array}$ \\
\hline 61 & 22 & $\begin{array}{c}258609.3 \\
(198438.3)\end{array}$ & $\begin{array}{l}-14288.86 \\
(40814.82)\end{array}$ & $\begin{array}{c}.721157 \\
(1.088869)\end{array}$ & $\begin{array}{l}.0667611 \\
(1.04933)\end{array}$ & $\begin{array}{c}.6099141 \\
(.2801915)\end{array}$ & 18 & $\begin{array}{c}289713.9 \\
(205773.6)\end{array}$ & $\begin{array}{l}-17782.77 \\
(44789.1)\end{array}$ & $\begin{array}{c}.812004 \\
(1.190979)\end{array}$ & $\begin{array}{c}-.022537 \\
(1.146449)\end{array}$ & $\begin{array}{c}.6410121 \\
(.1385294)\end{array}$ \\
\hline 62 & 10 & $\begin{array}{c}351069.2 \\
(172654.3)\end{array}$ & $\begin{array}{l}-27619.75 \\
(29043.77)\end{array}$ & $\begin{array}{c}.8421918 \\
(.8781459)\end{array}$ & $\begin{array}{c}-.0541895 \\
(.85023)\end{array}$ & $\begin{array}{c}.647954 \\
(.2907268)\end{array}$ & 8 & $\begin{array}{c}359734.2 \\
(182561.5)\end{array}$ & $\begin{array}{l}-31059.02 \\
(31770.1)\end{array}$ & $\begin{array}{l}.9293686 \\
(.971219)\end{array}$ & $\begin{array}{l}-.1401263 \\
(.9391488)\end{array}$ & $\begin{array}{c}.6576388 \\
(.1237059)\end{array}$ \\
\hline 63 & 9 & $\begin{array}{c}196219 \\
(225673.7)\end{array}$ & $\begin{array}{l}-10054.09 \\
(59636.26)\end{array}$ & $\begin{array}{c}.5490527 \\
(6.162938)\end{array}$ & $\begin{array}{c}.2465746 \\
(6.045916)\end{array}$ & $\begin{array}{c}.5741457 \\
(.1847222)\end{array}$ & 9 & $\begin{array}{c}196219 \\
(225673.7)\end{array}$ & $\begin{array}{l}-10054.09 \\
(59636.26)\end{array}$ & $\begin{array}{c}.5490527 \\
(6.162938)\end{array}$ & $\begin{array}{c}.2465746 \\
(6.045916)\end{array}$ & $\begin{array}{c}.5741457 \\
(.1847222)\end{array}$ \\
\hline 64 & 3 & $\begin{array}{c}161003.3 \\
(104928.5)\end{array}$ & $\begin{array}{l}-25537.47 \\
(17519.18)\end{array}$ & $\begin{array}{c}1.466859 \\
(.5948706)\end{array}$ & $\begin{array}{l}-.6679646 \\
(.4490144)\end{array}$ & $\begin{array}{c}.6523787 \\
(.2216944)\end{array}$ & 3 & $\begin{array}{c}161003.3 \\
(104928.5)\end{array}$ & $\begin{array}{l}-25537.47 \\
(17519.18)\end{array}$ & $\begin{array}{c}1.466859 \\
(.5948706)\end{array}$ & $\begin{array}{l}-.6679646 \\
(.4490144)\end{array}$ & $\begin{array}{c}.6523787 \\
(.2216944)\end{array}$ \\
\hline Total & 1327 & $\begin{array}{l}89288.54 \\
(163987)\end{array}$ & $\begin{array}{c}1304.938 \\
(110193.4)\end{array}$ & $\begin{array}{l}-.0498938 \\
(3.577429)\end{array}$ & $\begin{array}{c}.8142855 \\
(3.573245)\end{array}$ & $\begin{array}{c}0 \\
(.2572404)\end{array}$ & 278 & $\begin{array}{c}405327.3 \\
(163834.9)\end{array}$ & $\begin{array}{c}-12355.3 \\
(37396.78)\end{array}$ & $\begin{array}{c}.5263702 \\
(2.125417)\end{array}$ & $\begin{array}{c}.2427403 \\
(2.080865)\end{array}$ & $\begin{array}{c}.6208985 \\
(.0957386)\end{array}$ \\
\hline
\end{tabular}


International Business \& Economics Research Journal

Volume 2, Number 3

Tab 3: Lifetime SS incentives, Medians by Sector and age (years 1988-1992). Std. Dev. in parentheses

\begin{tabular}{|c|c|c|c|c|c|c|c|c|c|c|c|c|}
\hline \multirow[t]{2}{*}{ Age } & \multicolumn{4}{|c|}{ Public Sector } & \multicolumn{4}{|c|}{ Private Sector } & \multicolumn{4}{|c|}{ Private Sector (Eligible) } \\
\hline & PV* & $\mathbf{O V}^{*}$ & RMCV & MTV & PV* & $\mathbf{O V}^{*}$ & RMCV & MTV & PV* & OV & RMCV & MTV \\
\hline \multirow[t]{2}{*}{48} & 10839.72 & 98168.22 & -2.127117 & -12332.61 & 303551.2 & 489431.5 & -1.360727 & -282994.8 & -22494.69 & 6660.563 & -.8502559 & -22494.69 \\
\hline & $(144753.3)$ & $(224879.5)$ & $(2.55139)$ & $(153925.7)$ & (213176.6) & $(348296.8)$ & (3.799934) & $(233372.5)$ & $(23076.12)$ & $(62189.13)$ & $(.951555)$ & $(14559.68)$ \\
\hline \multirow[t]{2}{*}{49} & 1580.281 & 77505.09 & -2.603156 & -6458.828 & 320409.5 & 501501.9 & -2.39854 & -264910.3 & 4067.469 & 50479.22 & -1.933819 & -4008.047 \\
\hline & $(100460.4)$ & $(163742.1)$ & $(1.777035)$ & (109693.7) & (198215.2) & (317079.5) & $(4.836712)$ & $(288181.5)$ & $(13443.61)$ & $(51053.84)$ & $(1.114621)$ & $(4740.183)$ \\
\hline \multirow[t]{2}{*}{50} & -5150.125 & 53552.78 & -2.390772 & -9874.391 & 253913.5 & 423887.8 & -2.439919 & -227458.9 & 11740.94 & 83140.88 & -2.575255 & -8017.5 \\
\hline & $(92669.72)$ & $(162185)$ & $(1.409794)$ & $(96246.58)$ & $(195502)$ & (299889.7) & $(3.877915)$ & $(245143.4)$ & $(4806.337)$ & $(27342.55)$ & $(.8806281)$ & $(10616.28)$ \\
\hline \multirow[t]{2}{*}{51} & -9471.625 & 67997.84 & -.593918 & -11993.41 & 252167.2 & 416825.8 & -.9674044 & -203426.1 & 9399.875 & 64626.81 & -2.885279 & 7592.625 \\
\hline & (74313.34) & (190834.8) & $(1.150193)$ & $(75750.17)$ & (201429.9) & (323963.1) & $(4.639748)$ & $(266241.1)$ & $(21429.94)$ & $(40144.98)$ & $(1.259563)$ & $(20487.5)$ \\
\hline \multirow[t]{2}{*}{52} & -7653.25 & 102987.6 & -.4862249 & -12042.25 & 235505.2 & 395099.6 & -.9198551 & -167882.5 & -11621.42 & 45333.84 & -.2972168 & -12054.67 \\
\hline & $(84188.11)$ & (188074.6) & $(1.32521)$ & $(83719.35)$ & $(185809.1)$ & (309978.2) & $(5.421961)$ & $(259452.6)$ & $(25172.23)$ & $(62540.21)$ & $(.8097276)$ & (22027.08) \\
\hline \multirow[t]{2}{*}{53} & -9401.734 & 94802.38 & -.4159189 & -22187.28 & 168156.8 & 340834.5 & -.6838517 & -154548.8 & -15799.25 & 34097.86 & -.3932401 & -17173.05 \\
\hline & (112533.9) & (232509.9) & (1.716636) & (96277.28) & (207139.4) & (339550.2) & (3.908437) & (230806.3) & $(24367.92)$ & (95304.53) & $(4.560858)$ & (165427.7) \\
\hline \multirow[t]{2}{*}{54} & -6103.375 & 51037.13 & -.593887 & -17681.69 & 144530.5 & 287027.1 & -.8125622 & -66544.32 & -19949.73 & 5905.234 & -.3622962 & -25573.47 \\
\hline & (82316.11) & (175483.1) & (1.661865) & (77467.82) & (188279.3) & (299689.5) & $(4.256293)$ & (225786.1) & (22114.31) & (77753.34) & $(.7575284)$ & (18489.49) \\
\hline \multirow[t]{2}{*}{55} & -7647.375 & 46293.03 & -1.219239 & -16765.25 & 124846.9 & 254020.6 & -.8438491 & -80752.74 & -14990.88 & 27532.38 & -.5169994 & -18501.56 \\
\hline & (65743.17) & (151653.7) & (1.793177) & (76253.22) & (172221.7) & (278776.5) & $(2.30452)$ & (175833.2) & (32659.75) & (93445.63) & $(.8049237)$ & (15123.71) \\
\hline \multirow[t]{2}{*}{56} & -13417.13 & 11403 & -1.466683 & -18626.38 & 126834.3 & 228535.3 & -.9225606 & -67322.15 & -13427.56 & 23992.81 & -.542997 & -13773.16 \\
\hline & (42877.49) & (72978.96) & $(1.825435)$ & (67301.48) & (137909.6) & (200896.6) & (3.526936) & (168971.2) & (39553.87) & (102965.6) & $(.8026623)$ & (18942.49) \\
\hline \multirow[t]{2}{*}{57} & -13072.38 & 13360.19 & -.8716284 & -20156.63 & 113828.6 & 204700.7 & -.9917951 & -85924.63 & -6893.422 & 18223.81 & -.704767 & -11546.28 \\
\hline & (37408.19) & (70650.3) & (2.119869) & (69981.4) & (142443) & (198098.3) & (3.362172) & $(16309$ & (19501.32) & (51987.34) & $(.586)$ & (18545.49) \\
\hline \multirow[t]{2}{*}{58} & -21375.94 & 1232.063 & -.8130783 & -29792.22 & 110039.9 & 179715.3 & -1.121289 & -104272.6 & -6510.383 & 32595.75 & -1.04723 & -10240.16 \\
\hline & (32350.61) & (50360.84) & (1.758538) & $(56330.64)$ & (125985) & (170564.9) & (2.161738) & (142385.9) & (8911.465) & (22834.81) & $(.2901567)$ & (7275.996) \\
\hline \multirow[t]{2}{*}{59} & -25344.5 & -2320.031 & -.6922038 & -28899.77 & 122024.2 & 178529.7 & -7.193488 & 122024.2 & -8241.938 & 10079.8 & -1.184129 & -8241.938 \\
\hline & (25454.91) & (41874.53) & $(1.02025)$ & (30477.82) & (123640.9) & (162822.2) & (2.946799) & $(1236$ & (18780.86) & (30086.32) & (1.025367) & (18780.86) \\
\hline \multirow[t]{2}{*}{60} & -26526.28 & -10149.78 & -.2780949 & -28625.44 & -13227.75 & 3037.203 & -.496588 & -13227.75 & -12827.59 & 6018.344 & -.6046442 & -12827.59 \\
\hline & (43105.99) & (75791.67) & (1.188546) & (28485.07) & $(48797.44)$ & $(94240.16)$ & (1.211376) & (18979.98) & (53684.67) & $(104228.2)$ & (1.229069) & $(18457.2)$ \\
\hline \multirow[t]{2}{*}{61} & -31044.63 & -15990.91 & -.1288565 & -32116.78 & -14288.86 & -488.3984 & -.285364 & -14288.86 & -17782.77 & -4525.063 & -.276896 & -17782.77 \\
\hline & (58668.54) & (81977.28) & $(.8622808)$ & (74462.24) & (46317.13) & (76875.72) & (.6111267) & $(37484.19)$ & (51117.43) & (85273.17) & $(.6441632)$ & $(40858.28)$ \\
\hline \multirow[t]{2}{*}{62} & -26067.97 & -13784.95 & -.1884129 & -27195.36 & -27619.75 & -7337.563 & -.2184145 & -27619.75 & -31059.02 & -11066.22 & -.2610065 & -31059.02 \\
\hline & $(58145.6)$ & (76717.31) & (1.567384) & (69461.15) & (30526.36) & (40643.13) & $(.5640732)$ & (28009.41) & (33619.33) & (45626.41) & $(.6366335)$ & (30454.83) \\
\hline \multirow[t]{2}{*}{63} & -26373.25 & -9497.523 & -1.292689 & -29326.28 & -10054.09 & 2003.938 & -.8844218 & -10054.09 & -10054.09 & 2003.938 & -8844218 & -10054.09 \\
\hline & (125122.8) & (162897.8) & (1.633382) & $(76027.55)$ & $(59632.56)$ & (64181.09) & (5.83038) & (59646.91) & $(59632.56)$ & (64181.09) & $(5.83038)$ & (59646.91) \\
\hline \multirow[t]{2}{*}{64} & -33958.32 & -20409.8 & -.3528753 & -33958.32 & -25537.47 & -20266.39 & .0944008 & -25537.47 & -25537.47 & -20266.39 & .0944008 & -25537.47 \\
\hline & (116676.8) & (147015) & $(2.112281)$ & (94756.93) & (17519.18) & (13379.33) & $(.3433084)$ & (17519.18) & (17519.18) & (13379.33) & $(.3433084)$ & (17519.18) \\
\hline \multirow[t]{2}{*}{ Total } & -10028.78 & 38808.27 & $\begin{array}{l}-.7292454 \\
\end{array}$ & -18485.98 & 174795 & 327970.7 & -1.048387 & -134422.3 & -12297.47 & 20507.7 & -.6505887 & -13227.75 \\
\hline & (86290.75) & (166695.1) & $(1.766782)$ & $(86841.1)$ & (200071.6) & (322432.6) & 4.096514 & (238175.4) & (34863.94) & (78899.61) & $(2.098419)$ & (54713.38) \\
\hline
\end{tabular}

*(1992 lira divided by 10000)

-1.048387
$-4.096514-(238175.4)$

$\begin{array}{lll}(34863.94) & (78899.61) & (2.098419)\end{array}$

(54713.38) 
Table 4: Major features of the SS system prior to and after 1990s reforms*

\begin{tabular}{|c|c|c|c|c|c|c|c|c|c|}
\hline \multirow[t]{2}{*}{ Years } & \multicolumn{2}{|c|}{ Seniority Pensions } & \multicolumn{2}{|c|}{ Old age Pensions } & \multirow{2}{*}{$\begin{array}{c}\text { SS } \\
\text { payroll } \\
\text { tax }\end{array}$} & \multirow{2}{*}{$\begin{array}{c}\text { Pensions } \\
\text { Indexation } \\
\quad \text { Rate }\end{array}$} & \multirow[t]{2}{*}{ Pension formula } & \multirow[t]{2}{*}{$\begin{array}{l}\text { Yearly interest } \\
\text { rate (nominal) }\end{array}$} & \multirow{2}{*}{$\begin{array}{c}\text { Time span for } \\
\text { "Pensionable } \\
\text { earnings" } \\
\text { computation } \\
\text { (average of wages of } \\
\text { the last: } \\
\end{array}$} \\
\hline & Age & Contributions & $\begin{array}{c}\text { Normal } \\
\text { Age }\end{array}$ & Contributions & & & & & \\
\hline 1988-1992 & - & $\begin{array}{l}35 \text { years } \\
\text { (20) no more } \\
\text { than } 40\end{array}$ & 60 & 15 & 26.4 & $\begin{array}{l}\text { Wage } \\
\text { growth }\end{array}$ & \multirow{4}{*}{ Defined Benefits } & $\begin{array}{l}2 \% \text { and decreasing } \\
\text { according to wage } \\
\text { caps (more than } \\
2 \% \text { and no caps) }\end{array}$ & $\begin{array}{c}5 \text { years } \\
\text { (approximately } 1 \\
\text { year) }\end{array}$ \\
\hline $\begin{array}{l}1993 \\
\text { (Amato } \\
\text { Reform: } \\
\text { transition) }\end{array}$ & - & $\begin{array}{l}35 \text { and no } \\
\text { more than } 40\end{array}$ & 60 & 16 & \multirow{3}{*}{27.17} & \multirow{4}{*}{$\begin{array}{l}\text { Price } \\
\text { growth }\end{array}$} & & \multirow{4}{*}{$\begin{array}{l}2 \% \text { (decreasing } \\
\text { according to wage } \\
\text { caps and earning } \\
\text { brackets) }+1 \% \\
\text { yearly indexation } \\
\text { of wages entering } \\
\text { the pensionable } \\
\text { earnings for the } \\
\text { part of pension } \\
\text { maturated from } \\
1993 \text { to retirement } \\
\text { date }\end{array}$} & $\begin{array}{l}\text { Same as prior to } \\
\text { reform }+50 \% \text { period } \\
\text { from } 1 / 1 / 93 \text { to } \\
\text { retirement date }\end{array}$ \\
\hline $\begin{array}{l}1993 \text { reform } \\
\text { regime }\end{array}$ & & & 65 & 20 & & & & & Whole working life \\
\hline 1994 & - & $\begin{array}{l}35 \text { (between } 21 \\
\text { and } 35 \text { ), and no } \\
\text { more than } 40\end{array}$ & 61 & 16 & & & & & \multirow{2}{*}{$\begin{array}{l}\text { Same as } 93+50 \% \text { of } \\
\text { time between } 1 / 1 / 93 \\
\text { and } 31 / 1 / 96+66.6 \% \text { of } \\
\text { time from } 1 / 2 / 96 \text { to } \\
\text { retirement date }\end{array}$} \\
\hline $\begin{array}{l}1995 \\
\text { (Dini Reform: } \\
\text { transition) }\end{array}$ & & $\begin{array}{l}35 \text { and less } \\
\text { than } 40\end{array}$ & 62 & 17 & \multirow{2}{*}{32.7} & & $\begin{array}{l}\text { Defined Benefits } \\
(+ \text { Defined } \\
\text { Contribution } \\
\text { Correction for } \\
\text { younger workers }) \\
\end{array}$ & & \\
\hline $\begin{array}{l}1995 \text { reform } \\
\text { Regime }\end{array}$ & \multicolumn{2}{|c|}{$\begin{array}{l}\text { Seniority Pensions } \\
\text { Disappear }\end{array}$} & \multicolumn{2}{|c|}{$\begin{array}{c}\text { Either } 57 \text { to } 65 \text { age and at } \\
\text { least } 35 \text { years of } \\
\text { contributions } \\
\text { or } 40 \text { years of } \\
\text { contributions and any age }\end{array}$} & & & Defined Contribution & $\begin{array}{l}\text { Long run GDP } \\
\text { growth rate }\end{array}$ & Whole working life \\
\hline
\end{tabular}

* Public Sector in parentheses, if different from Private Sector. If not specified changes in the transitional phase apply to workers who had paid contributions for at least 15 years by $1 / 1 / 1993$.

* Since 1994 a penalization on retirement before 35 years of contributions was introduced: about $1.5 \%$ of pension benefit decrease for each contribution payment year missing to 35 . 
International Business \& Economics Research Journal

Volume 2, Number 3

Table 5: Variation rates of SS incentives (with respect to pre-1993 reform values): medians (years 1993-95, eligible workers)

\begin{tabular}{|c|c|c|c|c|c|c|c|c|c|c|c|c|c|c|c|c|}
\hline \multirow[t]{2}{*}{ Age } & \multicolumn{8}{|c|}{ Public Sector } & \multicolumn{8}{|c|}{ Private Sector } \\
\hline & Obs & SSW $^{*}$ & Accrual* & RMCR & PV* & $\mathrm{OV}^{*}$ & RMCV & MTV & Obs & SSW* & Accrual* & RMCR & $\mathbf{P V}^{*}$ & $\mathrm{OV}^{*}$ & RMCV & MTV \\
\hline 48 & 27 & -.365975 & .363114 & .654430 & .4827827 & -.0488921 & .2495057 & -.2847711 & 6 & -.231925 & .5774409 & .613168 & .5774409 & -4.161929 & .4390195 & .311342 \\
\hline 49 & 24 & -.317399 & .435577 & .716645 & .297922 & -1.409981 & .0470935 & .284247 & 16 & -.203781 & -.3572607 & .509000 & -.3572607 & .4142129 & .4609412 & .399090 \\
\hline 50 & 22 & -.345088 & .794376 & .968854 & .7444188 & 1.172522 & -.0064713 & .625347 & 12 & -.199188 & -.2668325 & .039166 & -.3515521 & 7.536994 & -.0603352 & -.266832 \\
\hline 51 & 23 & -.292079 & -.206359 & .28296 & -.2063594 & .3624161 & -.1794049 & -.2063594 & 20 & -.194595 & -.1920994 & -.065942 & -.1925076 & -.0606705 & .2717675 & -.190219 \\
\hline 52 & 29 & -.241866 & .680724 & 1.49319 & .242385 & -.0316331 & .026193 & .242385 & 29 & -.190005 & -.1834596 & -.057211 & -.1834596 & -.0620399 & .1821364 & -.18258 \\
\hline 53 & 25 & -.219 & -.157247 & .231592 & -.1880448 & 2.161469 & -.1171264 & -.1821777 & 24 & -.185422 & -.1703583 & -.060237 & -.1703583 & -.6688835 & .1172593 & -.169063 \\
\hline 54 & 25 & -.217307 & -.360173 & -.23394 & -.3685321 & -1.237383 & -.2473392 & -.3601733 & 22 & -.180847 & -.1682545 & -.055575 & -.1682545 & .3540232 & -.2763237 & -.16084 \\
\hline 55 & 27 & -.188688 & -.336760 & -.60753 & -.3569005 & -.3434569 & -.4717673 & -.258079 & 26 & -.176283 & -.1513721 & -.053428 & -.168487 & -.1729802 & -.2449695 & -.124581 \\
\hline 56 & 28 & -.184012 & -.178832 & .222642 & -.1788324 & .3542378 & .0251402 & -.0767522 & 18 & -.171732 & -.0903572 & .229301 & -.1180138 & .536287 & .1080429 & -.110438 \\
\hline 57 & 18 & -.180696 & -.169259 & .592111 & -.1821547 & -.1003917 & .1145131 & -.1691965 & 17 & -.178800 & -.1677022 & 141895 & -.1794966 & -.0737624 & -.0051497 & -.118074 \\
\hline 58 & 34 & -.175329 & .393031 & 2.05138 & .3930319 & 4.598944 & -.2663664 & .3281096 & 15 & -.162672 & -.1517393 & -.034772 & -.1438016 & .2887193 & -.2638882 & -.174517 \\
\hline 59 & 27 & -.170796 & -.730958 & -1.2306 & -.2780257 & -.8337328 & .1348159 & -.1888919 & 11 & -.170277 & -.1325952 & -.072114 & -.1324699 & -1.157753 & -.3252686 & -.132469 \\
\hline 60 & 29 & -.153680 & -.159947 & 2.20065 & -.1606108 & .1204561 & -.0270803 & -.1606075 & 15 & -.165800 & -.1408412 & -.035563 & -.1303312 & -.1225671 & -.0706914 & -.140841 \\
\hline 61 & 27 & -.161788 & .577651 & 1.116 & .2699801 & 1.246237 & -.4812537 & .2699801 & 7 & -.180761 & -.1811029 & 2.44957 & -.1811029 & .4182815 & -.020722 & -.181102 \\
\hline 62 & 24 & -.166984 & -1.04449 & -.93236 & -1.044491 & -1.051757 & 1.279261 & -1.045837 & 5 & -.144773 & -.2261251 & .064845 & -.2261251 & .0682891 & -.0382527 & -.226125 \\
\hline 63 & 18 & -.150341 & .419885 & 1.51492 & .5110015 & .6510411 & -3.913524 & .2075815 & 5 & -.228748 & -.1883238 & .754318 & -.1883238 & .2042271 & -.1697878 & -.188323 \\
\hline 64 & 7 & -.135966 & -.147679 & 1.01926 & -.1476795 & .0253316 & 2.684359 & -.1476795 & 3 & -.135966 & -.1625848 & .068965 & -.1625848 & .022799 & -.0923983 & -.162584 \\
\hline Total & 414 & -.199188 & -.153560 & .453773 & -.1604561 & .0072168 & -.0320772 & -.1568635 & 251 & -.185198 & -.1697106 & -.043947 & -.170434 & -.0439842 & .0385665 & -.159780 \\
\hline
\end{tabular}




\section{Endnotes}

1 The main contributions are from Brugiavini (1999), Blondal and Scarpetta (1998), Miniaci (1998), Spataro (2000) Brugiavini and Peracchi (2001) and Colombino. See Spataro (2002) for a review of the results.

2 Precisely, Bosi (1995 and 1997) has shown that this will be true, at the steady state, if the GDP growth rate will at least equal the discount rate used in the pension formula (i.e. 1.5\%). For critical reviews of recent Italian reforms see Castellino (1995), Gronchi (1995), Onofri (1998) and Vitaletti (2000). For the main macroeconomic features of the reforms see Bosi (1995 and 1997), while the works by Ferraresi and Fornero (2000) shed light on short run and long-run early retirement incentives, respectively.

3 Besides the excessive length of the transition phase, which will maintain significant early retirement incentives and wealth windfall gains for the baby boomers cohorts, the other major criticisms concern the regime phase: the lack of economic growth indexation of benefits, the excessive level of the contribution rates, which would impede the possibility of a real diversification; the difference between the actual and the computation payroll-tax and, finally, the permanence of several National Funds and differences in the pension rules among sectors.

$4 \quad$ For the sake of simplicity I abstract from survivor benefits and survival probabilities. The latter are however accounted for in the estimations of all parameters presented in the section Finally, I assume that individuals start paying contributions at the beginning of their working careers.

5 The analysis of SS systems optimality was presented in the seminal work by Aaron (1966); the reconsideration of such conditions under endogeneity assumption of labor supply is provided by $\mathrm{Hu}$ (1979) and Breyer and Straub (1993). For a macroeconomic, static analysis of the links between employment and social security see also Casarosa (1996).

This is property does not hold in case the subjective discount rate $(\beta)$ is different from the interest rate. A deeper discussion of this case is more complex and beyond the scope of the present work; however, as an example, it can be shown that in a funded system and for reasonable values of the wage growth rate and the interest rate, the MCR will be greater than (lower or equal to) the current wage if and only if $\beta<(\geq) r$. (The formal demonstration of this proposition is available upon request to the author).

7 For the sake of comparability with previous estimates carried out by Brugiavini and Peracchi (2001), I assume an intertemporal discount rate factor $\beta$ of 0.985 , the marginal utility of leisure $(k)$ equal to 1.25 , a risk aversion parameter ( $a$ ) equal to unity and $r$ equal to $3 \%$, survival probabilities are taken from tables provided by ISTAT for the years considered, while future pensions (before reforms) are indexed by $1.5 \%$ per year. I have also computed all incentives with different specifications of parameters (comprising also the case in which $\beta=1 /(1+r)$, which however do not change the qualitative pattern of the incentives and conclusions.

See Greene (1999) for Heckman's correction model. The exact regression specifications and results for contributions and wages are available under request to the author.

9 As anticipated, I show the results for the whole Public Sector sub sample since differences with eligible individuals are in this case negligible.

10

Although the small dimension of such subset suggests caution in drawing general conclusions from statistical inference, the similarity with the Public Sector values of both RMCR and MTV parameters seems a robust result. 
Notes 